\title{
LA FORTUNA DE GONGORA EN EL SIGLO XVIII
}

Si la única manera de medir el interés que se tiene por un autor en determinada época fuera la de percatarse del número de ediciones de sus obras publicadas en ella, poco tendríamos que decir de las aficiones gongorinas del siglo XviIr. Entre I700 y I800 no salieron de las prensas españolas más obras de Góngora que las Poesias coleccionadas por «Ramón Fernández», editadas en Madrid en I789, y unos pocos romances y letrillas publicados por Cerdá y Rico y López de Sedano en tres tomos del Parnaso Español, aparecidos entre 1770 y $\mathrm{I}_{782}{ }^{1}$. Evidentemente, las apariencias engañan. Pero hace treinta años, al menos, se creía que el siglo xvirr español representaba no sólo un período de decadencia en la literatura española, sino también en los gustos gongorinos: que el siglo no produjo más que críticas agrias o poco comprensivas, y, en su primera mitad, imitaciones en gran parte despreciables ${ }^{2}$. Sin embargo, aunque hay cierta verdad en esto, la época no está tan desprovista de interés para los estudios gongorinos como se suele creer. A pesar de los valiosos estudios del marqués de Valmar, de Menéndez y Pelayo, $y$, más recientemente, de Gerardo Diego, no será del todo inútil volver sobre ello ${ }^{3}$. Fácilmente se olvidan la sincera admiración de los poetas dieciochescos que rindieron homenaje a Góngora en sus imitaciones, y el respeto con que le trataron

1 Se trata de los tomos IV, págs. 253-265, VII, págs. I71-212, y IX, pági-. nas 368-37o. Cerdá editó los primeros cinco tomos y Sedano los demás (véase A. GonzÁl, el Boletín de la Real Academia de la Historia. 1949, CXXIV págs. 159, 166 y 176-7). Hubo varias impresiones de los tomos del Parnaso.

2 Veánse, por ejemplo, el prólogo a la Antologia poética en honor de Góngora de Gerardo DIEGo. Madrid, I926, págs. 59 y sigs., y el artículo de Dámaso Ar,onso, Góngora y la literatura contemporánea, escrito en 1927 y recogido en sus Estudios $y$ ensayos gongorinos. Madrid. 1955, págs. 532 y sigs.

3 Véanse el MARQUÉS DE VALMAR, Bosquejo histórico-crítico de la poesía castellana en el siglo XVIII (B. A. E. 6I, págs. V-CCXXXVII); MENúndEZ Y PELAYo, Historia de las ideas estéticas en España (ed. consultada: Santander, 1947), Tomo III passim; y el prólogo de Gerardo Drego a su Antología poética citada. 
la mayoría de los críticos que intentaron valorar sus obras. Al pasar revista a nombres de autores y sus obras, que ya son en parte conocidos gracias a los investigadores mencionados, trataremos de recalcar la calidad de las aficiones gongorinas de la época, procurando ver, sobre tođo, qué es lo que había en las obras de Góngora que atraía a los poetas. Quizá esto nos ayude a comprender por qué resultan tan malas la mayoría de sus imitaciones. Luego veremos cómo la crítica, reaccionando contra los imitadores, vino a malbaratar las obras de Góngora mismo.

Sabido es que, durante las primeras décadas del siglo, los poetas y dramaturgos españoles siguieron imitando y glosando a Góngora de la nisma manera que sus antecesores del siglo xvir. Calderón y otros de su tiempo habían glosado poemas gongorinos en sus dramas, y Cañizares, a principios del xvirr, no les iba a la zaga (sino estilísticamente) en los suyos. En su comedia $E l$ dómine Lucas, por ejemplo, se cantan los primeros cuatro versos de "Servía en Orán al rey", aunque sin mucho motivo ${ }^{1}$. Pero Cañizares no estuvo siempre torpe en su empleo de los versos y estilo gongorinos, y en su zarzuela Angélica y Medoro se encuentran recuerdos del romance «En un pastoral albuergue», cuyo tema y manera no desafinan en su contexto cañizaresco ${ }^{2}$.

Esta zarzuela de Cañizares fue representada en Madrid en abril de I722 y publicada probablemente poco después. $Y$, antes y después de esas fechas, hubo bastantes manifestaciones en España del alto aprecio en que se tenía tanto al Góngora «difícil", como al Góngora de los romances más sencillos y letrillas. Pero la más importante de estas manifestaciones, sin duda alguna, fue la Soledad tercera siguiendo a las dos que dexó escritas cl principe de los poctas liricos de España don Luis de Góngora, compuesta por don Joseph León y Mansilla, e impresa en Córdoba en I7I8.

Ya desde el principio de su obra León y Mansilla demuestra tener conocimientos gongorinos nada despreciables. Se arrojó temerario «a sacrificarse a las llamas de la emulación” ${ }^{3}$, pero no se arrojó sin mucha preparación previa del terreno, llamando con justicia a su obra «poéticos estudios» 4. Seguir la supuesta intención de Góngora en "expresar en [las Soledades] las quatro edades de el hombrey, y saber que a la tercera le

1 Véase El dómine Lucas, jornada primera.

2 Véase la reciente edición de la zarzuela hecha por JuL,IUS A. Molinaro y WARREN T. MCCready. Torino, I954. Para más datos véanse Modern Language Review, IV, I960, págs. I25-6, y A. PARDUCCI, La fortuna dell' Orlando furioso nel teatro spagnolo, (Giornale storico della letteratura italiana, supplemento número 26 ), Torino, 1937, págs. I02-8.

3 Ob. cit. Dedicatoria.

- Idem, loc. cit. 
correspondía "el doble exercicio de la Venatoria casa» ${ }^{1}$ no suponía mucho trabajo, aunque Gerardo Diego releva su interés ${ }^{2}$. Pero sólo una muy profunda comprensión de la obra de Góngora y de los comentarios llevaría al autor a desarrollar una teoría del claro-oscuro en su "Prólogo a el Docto Lector». Y su concepto del léxico aristocrático de Góngora es igualmente interesante. El lo emplea en su poema, «no porque se permita, ni tal pretendo, usar de vozes, que no sean nacidas en nuestro clima, o recibidas en nuestro idioma: sino por $\bar{q}$ la travazón de ellas, y la colocación de las frases, las haga para los vulgares estrañas, peregrinas, e inauditas: y para los doctos proprias» ${ }^{3}$. Declara asimismo seguir a Góngora en ello, "ya que él en sus (no como deven) veneradas obras, quisiese fuesen sólo estudio de la erudición más elevada: me fue preciso seguirle norte en lo $\bar{q}$ me fue posible» ${ }^{4}$. En otro lugar se propone hacer todo lo posible por prescindir en su poema del estilo "sino rústico, ordinario" ${ }^{5}$.

Desgraciadamente, por muy conocedor que fuese León y Mansilla del modelo que intentaba seguir, carecía del genio necesario para hacer una continuación maestra de sus obras. Faltan muy pocos de los elementos de la poesía de Góngora en su tercera Soledad: léxico, dificultad ("en opinión de algunos", asevera León, hablando de sus propios versos en el prólogo, "no son inteligibles»), contraste de luz y sombra, tema de menosprecio de la corte y alabanza de la aldea. En cambio, falta el soberbio enlace de metáforas, tan característico de las Soledades de Góngora, y falta por completo la sutileza musical de don Luis, que tanto contribuye al sentido, a la unidad y a la fluidez de su obra. Sobre todo, León y Mansilla careció de inventiva. Casi siempre toma directamente de Góngora sus metáforas más 1lamativas, sin adaptarlas a su nuevo contexto. En un pasaje que describe las ventajas morales de la vida del campo encontramos, por ejemplo, lo siguiente:

Aqui las Aves órganos de pluma Entre las bellas flores me hazen salva: Sin que caliente el Alva Bíbora torpe: cauteloso llanto. Carcel de Minos: llanto de Perilo Tienen sin uso aqui todas sus iras. Hasta el tirano Mar en blanda espuma Corona de su playa el duro espanto. ${ }^{6}$

1 Idem. Segunda aprobación de fray Joseph Ruiz.

2 Gqrardo Diego, prólogo citado, pág. 59.

3 Ob. cit. "Prólogo a el Docto Lector».

- Idem, loc. cit.

5 Idem, loc cit.

- Ob. cit., pág. 27. 
Las aves, "órganos de pluma», es evidente recuerdo de la descripción de los cisnes en la segunda Soledad ( $v$ 523), pero la imagen está evidentemente echada a perder por la idea bélica que sugiere la frase "me hazen salva» que la sigue. El mar que "corona» la playa es otro recuerdo de Góngora (II, vv. 24-5), pero, por su posición, refuerza el «duro espanto de la playa" en vez de ablandarlo ( No hablemos de la torpe repetición de (llanto" en dos versos consecutivos!). Incluso en los versos, no del todo malos, donde ha conseguido enlazar unas metáforas a través de varias frases, siempre pone algo que desentona. Véase, por ejemplo, su descripción de árboles y flores en la margen de un arroyo...

Dosel formando de sus ramas bellas,

$Y$ cortina en sus ojas esmaltadas,

A cuyo pie, lascivas no, serpientes,

Si de christal; hermosas le ceñian,

Que bordando en espumas

Las que el prado alentó flores hermosas,

Eran de blancas plumas

Nevados cisnes, o canoras Rosas ${ }^{1}$.

La idea del reflejo de las rosas bordado sobre las espumas del río no está mal después del dosel formado por las ramas y la cortina de las hojas. Pero ¿de dónde vienen esas serpientes de cristal entre tanta tela y bordaje? ¿A qué preguntar? Vienen, desde luego, como el dosel y las cortinas, y tantas otras bellezas de esta tercera Soledad, de Góngora ${ }^{2}$.

A pesar de lo fácil que resulta criticar a León y Mansilla, no se puede menos de admirar su erudición clásica y gongorina. Su Soledad es una verdadera obra de amor pedantesco. $\mathrm{Y}$ pocos otros poetas del siglo XVIII pusieron en sus innitaciones tanta comprensión (ni tantos plagios) del Góngora difícil. Por lo menos, supo no sólo reproducir mucho de lo que el mismo Góngora llamaba la "corteza» de las Soledades, sino también algo del misterio que encubría: el tema del desengaño y la crítica moral de la vida fastuosa de la corte. Llegó a captar casi todos los elementos de la técnica y de las ideas de Góngora, aunque nunca alcanzó a relacionarlos con completa coherencia.

Lo que León y Mansilla no supo apreciar plenamente fue la importancia de la estructuración en la obra de Góngora: la estrecha conexión entre

1 Ob. cit., págs. 14-I5.

2 Véanse el Polifemo, vv. 310-3II (dosel y celosías); Soledades. Dedicatoria - v. 23 (dosel), y I, v. 426 (sierpe de cristal). Citamos por las ediciones de DÁMaso Alonso, Góngora y el "Polifemo». Madrid, 1961, 2 tomos, y Las Soledades. Madrid, 1956, tercera edición publicada por Dámaso Alonso. 
los detalles y el todo, que la severa crítica de unos hombres como el abad de Rute y Pedro de Valencia le había exigido. Pero, al menos, León imitaba el estilo gongorino a través de todo un poema largo, lo cual era, ya de por sí, algo excepcional a principios del siglo xvirr. La mayoría de los poetas de aquella época tendían a servirse del gongorismo tan sólo para realzar momentáneamente el asunto que trataban. Ejemplo de ello es Gabriel Alvarez de Toledo, que lo usó de vez en cuando en su Burromaquia, para conseguir el necesario tono heroico-burlesco ${ }^{1}$. También lo usó, de la misma manera fragmentaria, el doctor Joseph Tafalla Negrete, cuya colección de poemas titulada Ramillete poético fue publicada en Zaragoza en I704, y, de nuevo, en I7I4. En la aprobación de la segunda edición de este libro se dice que la utilidad de su publicación es bien grande, "no siendo sus versos inferiores a los énfasis heroycos de Góngora, a las dulces suavidades de Lope, $[\mathrm{y}$ ] à las provechosas moralidades de los Leonardos [Argensola]". Efectivamente, la descripción del Ebro en la "Historia de los muchísimos desdenes de la Bella ingrata» y el poema "Bosquexo del altar de la compañia de Jesús» suministran algunas pocas frases cuya construcción es de evidente raíz culta ${ }^{2}$. Y el soneto en el que Tafalla Negrete "Pinta la hermosura de una dama» también recuerda lejanamente a Góngora en su principio - Mucho dorado pelo, en trença poca $=$ arcos las cejos, y la frente plata" ${ }^{3}$. Pero sólo en la «Descripción de las solemnes fiestas ...en la celebridad del Martirio y Beatificación de San Pedro Arbuésy encontramos marcadas huellas del estilo de Góngora y sus "énfasis heroicos» 4 , y aun alli falta el enlace de las atrevidas metáforas, tan fundamental para el gongorismo de buena ley.

No muy diferente de ellos fue el padre jesuita Joseph Butrón y Múxica, uno de los primeros en escribir una extensa obra religiosa en estilo gongorino en el siglo xvin. Sn largúsimo poema en octavas, Harmónica vida de Santa Teresa de Jesús, fue publicado en Madrid en I722, y contiene bastantes auténticos recuerdos de lecturas gongorinas. En la estrofa

1 Véanse B. A. F. 6I, pág. I I (Rebuzno segundo, vv. 73-80) y pág. I2 (Re* buzno segundo, vv. 21 7-224) por ejemplo, y lo que dice el MARQUÉs DE VAIMAR en su Bosqueio histórico-crítico, págs. XXXIII-XXXIV.

2 Véase TAFAl, A NEGRETF, ob., cit. ed. consultada: Zaragoza, I714, pág. II3, por ejemplo: «El Ebro cano, cuya barba vndosa, = en fugitivas ebras se dilata, = y texida, prolixa, $\mathbf{y}$ numerosa $=$ es trasparente sábana de plata, = padre de Antandra fue, deidad hermosa".

a ob. cit., pág. 164 .

- Ob. cit., pág. 305 ("Quantas hiló madejas el gusano = en futiles prisiones de su vida, etc.»), y pág. 306 ("Golfo la Iglesia toda se juzgava, = pues sólo Mar y Cielo se miravay). 
número CXVI, por ejemplo, el céfiro "peynaba el bosque umbroso» ${ }^{\mathbf{1}}$, y en la CCXXIV la descripción de un toro que ataca a un león recuerda. varios lugares de las Soledades ${ }^{2}$. Más tarde aún, Butrón usa la metáfora "bala con alas» para describir un sacre casi del mismo modo que Góngora en la segunda Soledad ${ }^{3}$. Pero, aun cuando no faltan los hipérbatos, algunas de las otras construcciones más comunes en Góngora, y bastantes metáforas atrevidas - algunas de ellas tomadas del mismo Góngora - el padre Butrón no emplea tales recursos estilísticos con la misma constancia que el autor de las Soledades o el Polifemo. Mientras que Góngora evita continuamente lo concreto porque le parece carecer de fuerza poética, el padre Butrón no intenta evitarlo siempre. Usa metáforas tan sólo para que los objetos que describe parezcan más sublimes en determinados momentos. Su uso es adorno más que sustancia en el poema. Así, por ejemplo, nos da una metáfora tan trasparente como ubruto lunado", para explicarla en seguida con la palabra concreta (toro» (CCXXIV). En otros lugares amontona varias metáforas casi iguales de modo retórico para su valor puramente decorativo: técnica muy distinta de la de Góngora. Véase, entre otras, la descripción del toro ya mencionada que ataca al león, en la que Butrón nos suministra tres metáforas seguidas, todas ellas sacadas de portentos celestiales, resultando dos de ellas ociosas e inútiles:

Trueno con pill, centella anochecida

era el bruto, cometa con dos puntas,

cuya cólera pudo retorcida

dexar las fieras de pavor difuntas ${ }^{5}$.

Aquí tan sólo la metáfora del cometa resulta realmente afortunada, y las otras dos nada añaden (sino énfasis rettórico) a la fuerza poética dẹl pasaje.

No debe sorprendernos el que tales imitaciones de Góngora estén a la

1 Ob. cit., pág. 40. Coinpárese con el Polifemo, v. 59, por ejemplo.

2 Butrón se refiere al toro como «bruto lunado», lo cual połría ser recuerdo de Soledades, I, v. 3, o II, v. I9.

3 Véase Soledades, II, vv. 9 Io y sigs.

4 Aparte las metáforas ya citadas encontramos (Estrofa XVI) la frase "Clycies ágiles del viento" que recuerda a GóNGORA, Soledades, I, v. 372. La descripción por Butrón de la venida de la primavera, también de tipo marcadamente gongorino, parece original (Estrofa DCCXXXVII): «En hojas rudas dando sus colores = (Borrador verde) prólogo a las flores». El juego de palabras sobre "hojas" (del arbusto y del libro) recuerda una técnica muy usada de Góngora.

5 Ob. cit., pág. 79. Estrofa CCXXV. 
vez $\tan$ cerca y $\tan$ lejos del original. Ia necesidad de hacer innovaciones estilísticas había traído consigo en todas las artes, a principios del siglo XVIIr, una elaboración de los detalles exteriores del barroco. Lo mismo en la arquitectura de Pedro de Ribera o Leonardo de Figueroa que en la poesía de Tafalla Negrete y el padre Butrón, los detalles tenían una importancia en sí, no relacionada con el todo, como había sido el caso de la mejor arquitectura y poesía barrocas.

Sin embargo, el éxito del estilo gongorino en la década veinte no se debe todo a la moda decorativa. Por entonces vieron la luz ciertos notables elogios e imitaciones de Góngora escritos en el siglo xvIr, que habrán influido bastante sobre los autores del xvir por ser de quienes eran. Por aquellos años se publicaron varias nuevas ediciones e impresiones de las Comedias y Autos de Calderón ${ }^{1}$ - cuya deuda para con Góngora es notoria 2- y ediciones de las Comedias (Madrid, I722) y de los poemas (I720 y de nuevo en I729) y de Bances Candamo. En aquellos poemas de Bances, sobre todo, abundan las construcciones y metáforas de Góngora Caso muy conocido es el del largo poema "El César africano», pero también en algunos de los romances heroicos de Bances se encuentran rastros del giro gongorino, y en el idilio "Descripción y viaje del Tajo» no sólo hay metáforas tomadas del mismo Góngora, sino todo un largo elogio del poeta «a quien dictó Euterpe numerosa = soledades confusas» ${ }^{3}$.

En tales obras y en las del mismo Góngora encontraron muchos poetas españoles de la década treinta pauta para sus propias composiciones. Buen ejemplo de eilo es Gerardo Lobo, en cuyos poemas publicados antes de aquella década encontramos muy escasas huellas de la influen-

1 Véase E. M. WiLson, On the Pando editions of Calderón's Autos, en la Hispanic Review, XXVII, I959, págs. 324-344.

2 Véase sobre todo el artículo de E. J. GATEs, Góngora y Calderón, en la Hispanic Review. V, 1937, págs. 241-258. Sin duda se podrían citar bastantes recuerdos de Góngora en las obras de Calderón no mencionados por ella, como, por ejemplo, la locución de Mundo en El gran teatro del mundo que empieza "Autor generoso mio». Los versos que describen los dos luminares parecen recordar, en parte, las Soledades, I, vv. 6o-83.

3 Véase, como ejemplo del estilo gongorino, el Romance Heroico I (Obras lyricas ed. FERNANDo GUTTÉRREZ. Barcelona, 1949, págs. 95-6): "Y después que (los términos cerrados $=$ de Alcides) a la vndosa cristalina $=$ espumosa garganta del estrecho $=$ fances muradas dan, Calpe y Abyla.... En la Descripción y viaje ael Tajo, véase la descripción del río como "vibora de cristal» (ed. cit., pág. 72, compárese Soledades, I, v. 426), y el largo extracto en la Antologia de GERARDo DiEGo, págs. I9I-2. 
cia culta y gongorina ${ }^{1}$. Desde entonces en adelante, en cambio, aparecen en su poesía numerosísimos rasgos de Góngora y Calderón. Como un amigo jesuita, padre Luis de Losada, observaba más tarde, en un poema escrito a Lobo, éste último robaba «inventiva a Calderón»... «y a Góngora elevación ${ }^{2}$. Sus poemas heroicos, sobre todo -el Rasgo épico de Orán y los dos Sitios de Lérida y Campo mayor-- huelen a Góngora: los cañones "escupen" sus balas, o son "vívoras de bronze», y la bala misma es "monstruo orbiculas de hierro adusto»; una flota de barcos de guerra es una "selva nadante sobre el Mar»; siete de ellos son "garzas de pino, cuyas plumas = las fatigas escriben en su empleo = siendo tinta común de las espumas $=$ el sudor criminal de tanto reo" ${ }^{3}$. Sin embargo, Lobo, como los otros imitadores de Góngora que hemos examinado, se fijó más en la corteza de la obra de Góngora que en su lógica interior. Las bellezas externas le llamaron la atención, pero no su función dentro del poema. Notable ejemplo de esta mala comprensión de la importancia de la estructura en Góngora es su imitación del famoso soneto "Mientras por competir con tu cabello»" 4 . E1 tema del soneto de Lobo es casi el mismo: el poder de la muerte. El último verso es poco menos que idéntico: honor, riqueza, calidad y vida se trocarán "en polvo, en humo, en ilusión, en nada». Pero aunque Lobo ha logrado en este verso conservar el proceso gradual de lo material (polvo) hacia la nada, ha perdido la fuerza rítmica, regular, inexorable de Góngora ("en tierra, en humo, en polvo, en sombra, en nada») y no ha percibido su función dentro del soneto. Toda la estructuración correlativa del soneto de Góngora (que es lo que justifica plenamente el último verso plurimembre) ha quedado reducido en Lobo a los dos últimos versos ${ }^{5}$. Antes de ellos no se encuentra rasgo alguno de correlaciones en su soneto. Es evidente que el ritmo retórico del verso de

1 No aparecen en la edición de I724 los sonetos "No suspendas el passo, caminante" $\mathrm{y}$ "Esssas que el ocio me dictó algún dia», cuya deuda para con Góngora trataremos más adelante. Los poemas heroicos gongorinos - Rasgo épico. de la conquista de Orán, el Sitio de Campo-Mayor, y el Sitio, ataque y rendición de Lérida - fueron escritos en la década treinta. Alguno de ellos apareció suelto. en Barcelona en I732, y los tres fueron publicados en las Obras poéticas lyricas. de Lobo, en Madrid, 1738.

2 Véase Gerardo LoBo, Obvas poéticas. Madrid, I769, I, pág. 283.

3 Véanse Sitio de Lérida, estrofas IIX y LXXI, y Rasgo épico de la conquista. de Orán, estrofas XXII-XXIII.

4 Véase el soneto "No suspendas el passo, caninante" (en B. A. E. Tomo 6r, página 23.

5 Para el estudio de la estructura del soneto de Góngora, véase DÁmaso ALONSO, Estudios y ensayos gongorinos. Madrid, 1955, págs. 225-6. 
Góngora ha seducido a Lobo por sí mismo, no por su estreclia conexión con todo lo demás del soneto.

Otros recuerdos obvios de Góngora hay en los sonetos de Gerardo Lobo, y en uno de ellos imita abiertamente la dedicatoria del Polifemo, refiriéndose a su autor como "el Horacio cordobés», título muy común de Góngora en el siglo XVII ${ }^{1}$. Pero, a pesar de las pruebas que nos dan de lecturas gongorinas, no mejoran en nada nuestra opinión de la capacidad de Lobo como imitador de Góngora.

Huelga decir que tales imitaciones defectuosas no pasarían sin algún que otro comentario adverso. Los eruditos estudiosos de los clásicos difícilmente tolerarían la falta de lógica, las extravagancias y exageraciones de los que siguieron el estilo culto, y recordarían, sin duda, las críticas hechas en el siglo xvir por hombres tales como Cascales y Quevedo. Concretamente en 1725, Gregorio Mayáns y Siscar, en su Oración en alabanza de las obras de don Diego Saavedra Fajardo, citó la Culta latiniparla de Quevedo con evidente aprobación, al quejarse de algunos "necios atrevidos", que habían desfigurado tanto el lenguaje con locuciones poéticas, y alabado tanto "cierta algaravía", que se desconocía ya «el idioma universal» ${ }^{2}$. En otra obra del mismo año - la Oración en que se exhorta a seguir la verdadera idea de la eloquencia española - Mayáns vuelve a la carga con los mismos reparos, aseverando que «toda Europa desprecia, $i$ aun hace burla del extravagante modo de escribir que casi todos los españoles practican hoi» ${ }^{3}$. Sin duda, su conciencia de la mala opinión que se tenía de la literatura española en el extranjero empezaba a molestarle seriamente. Pero todavía no le llevaba a hablar mal de los escritores del siglo xvII que sus contemporáneos imitaban, aunque señalaba los peligros del estilo de Fray Hortensio Paravicino ${ }^{4}$. No atacaba, por entonces, a Góngora, al menos, e incluso le cita entre poetas de fines del siglo xvi y principios del xvir que «levantaron sus voces con harmoniosos números» ${ }^{5}$.

1 Se trata del soneto "Essas que el ocio me dictó algún dia». Gerardo DiEgo se refiere a él en su Antologia, pág. 6o, y cita otro - -Envidiosa es porción de tu blancuran--, pág. 196. Otros sonetos de Lobo hay igualmente gongorinos, como "Lstos, que mucho aljófar derretido" (Obras poéticas. Madrid, I769, II, pág. 224), y algún ronance también con rasgos del mismo estilo, como, por ejemplo, el que escribió al marqués de Ariza (Obras poéticas, ed. cit., pág. I 26 sobre todo), y la "Historia de Medoro y Zelima" (B. A. E. 6I, págs. 39-40).

2 Véase Mayáns. Ensayos ovatorios. Madrid, 1739, págs. 142-3.

3 Ensayos oratorios, ed. cit., pág. 178.

4 Ensayos ovatorios ed. cit., págs. I28-9. Las obras de Paravicino le parecian a Mayáns "obra de Aquimia, que si bien reluce como el oro, no vale mucho.»

5 Idem, pág. I27. 
Diez años más tarde, en cambio, la situación era ya distinta. Por fin, los críticos empezaban a creer que los defectos que notaban en los imitadores se encontraban también en el mismo Góngora: que el uso caprichoso del estilo culto en los imitadores se debía a los caprichos de él. En I735 Mayáns la emprende con Góngora, en latín. Era, sin duda, "hombre de gran ingenio y conocimientos admirables», decía, pero "iquién pudiera decir lo mismo de su estilo!» ${ }^{1}$. Sus unuevas palabras, atrevidas metáforas y transposiciones» constituían, para Mayáns, ahora «un error grave de la literatura» ${ }^{2}$. Sin embargo, es de notar que lo constituían no tanto por sí mismas, sino por sus malas consecuencias, porque «los hombres de saber inferior, quienes, si hablasen claramente, no tendrían importancia alguna, se creen muy inteligentes al escribir en estilo oscuro (siguiendo el ejemplo de Góngora), ya que el comprender lo que escriben y apenas entienden ellos mismos, exige gran inteligencia» ${ }^{3}$. Hasta cierto punto, pues, Mayáns sigue respetando a Góngora; son sus imitadores los que realmente le preocupan todavía; ellos son culpables, él queda relativamente inocente.

En 1737 todavía encontramos el mismo respeto para con Góngora, y desprecio para con sus imitadores en otros críticos importantes e inteligentes de la época. Los editores del Diario de los Literatos, que trataban, como Mayáns, de corregir las malas tendencias de la literatura de sus tiempos mediante la crítica pública de ellas, atacaron fuertemente, en aquel año, a uno de los muchos que habían seguido al padre Butrón en servirse del estilo culto para el elogio de santos. Se trataba de don Pedro Nolasco de Ozejo, cuya obra $E l$ sol de los anacoretas... la milagrosa vida de San Antonio Abad fue publicada en Madrid ese mismo año. Don Pedro Nolasco se había anticipado a sus críticos con una defensa de la obra, y esto permitió a los diaristas fustigar obra y defensa a la vez.

Ya en el poema mismo Pedro Nolasco había llamado la atención del lector sobre sus aficiones gongorinas con dos notas al margen: «el discretísimo Góngora» le llamaba en un lugar ${ }^{4}$. Luego, en su defensa, había

1 Véase Gregorio Majansio, Emmanuelis Martini Vita... Mantuae Carpetanorum, I735, pág. 6. "Scripsit [Martinus] eam sylvam ad imitationem primae Ludovici Gongorae, profundissimi ingenii, \& exquisitissimae eruditionis viri, famaeque etiam clarissimae. Utinam \& stilin.

2 Ob.c it., loc. cit. «scribendi genus adamavit, novis vocabulis refertum, translationibus \& transpositionibus audax, magno certe reipublicae literariae malo..."

3 Idem., loc. cit. - kcum imparis eruditionis homines, qui, si clare loquerentur, in nullo essent pretio; orationem obscurando (exemplo Gongorae) sibi videantur ingeniosi, quia magno ingenio opus est ad intelligendum id quod vix ipsi sciunt".

4 Ob. cit. Madrid, I737, pág. 45; también se cita a Góngora, pág. Io6. 
aseverado que toda su obra era imitación de «aquel grande ingenio de Andalucía don Luis de Góngorai 1. Ofrecía, asimismo, escribir un comentario extenso sobre su poema, al estilo de los escritos por Salcedo Coronel y Pellicer, y parece haber pensado seriamente en la posibilidad de que hubiera acaso superado a su modelo en su imitación. "No digo si en el rigor de las metáforas, y continuado argumento de alusiones, tropos y figuras me aventajé», afirma, "esso lo dirán personas de juicio desinteressadas, que harán justicia» ${ }^{2}$.

A fuer de personas desinteresadas, los diaristas procuraron hacerle justicia, tachándole fuertemente los neologismos, mala versificación y la "caprichosa y continua transposición y afectada gramática que se nota en todo el Poema» ${ }^{3}$. Aprovecharon la ocasión para lamentar las muchas malas imitaciones de Góngora, que, según ellos, sólo lograban desacreditar al gran poeta. $\mathrm{Y}$ afirmaron que el abuso del estilo culto había sido reprobado siempre por «todos los célebres poetas de España, por reconocer que con él usurpaban el nombre de cultos los poetas, que, sin ingenio, estudio, y demás partes necesarias, hacían a la poesía un mysterio, que sólo consistía en amontonar términos latinos, y bárbaros, sin saber ellos lo que significaban, ni entender lo que escrivían» ${ }^{4}$. Nótese, sin embargo, que la crítica de los diaristas implica una importante distinción entre Góngora y sus imitadores. Al quejarse justamente del capricho e ignorancia de éstos, su falta de coherencia y mal empleo de recursos estilísticos, dejan ver su respeto para con los conocimientos y la técnica del mismo Góngora.

Hasta esta fecha -r737- no hemos encontrado ninguna crítica tajante de Góngora en España en el siglo xvirr. Muchos le elogian y muchos procuran imitar su estilo, quién con más, quién con menos conocimiento del original. I os críticos distinguen entre las cualidades de Góngora y las de sus imitadores. Pero, ya desde la década veinte, se nota la creciente preocupación de los críticos por el abuso del estilo culto, responsable, según ellos, de la mala opinión que se tenía de la literatura española en el extranjero. $Y$ esta preocupación por el crédito nacional les lleva a fines de la década treinta, a atacar al mismo Góngora y otros autores cultos del siglo XVII, achacándoles las mismas faltas de capricho y voluntariedad que se echaban de ver en sus secuaces dieciochescos. Aparece, precisamente en I737, un crítico que parece ver a Gón-

1 Véase el Diario de los literatos de España. Tomo IV, Mađrid, I738, pág. 349.

2 Ob. cit., loc. cit.

3 Ob. cit., pág. 356. Para otra critica véase Diario, Tomo V, pág. 50.

Idem., pág. 357. 
gora completamente a través de sus imitadores. Se publica en Zaragoza la Poética de Luzán.

I,uzán iba mucho más allá de Mayáns en su crítica de Góngora. En varios lugares fustiga sus obras, sólo haciendo excepción de los romances. En realidad, atribuye toda la decadencia de la literatura española desde el principio de su libro a Góngora, aunque Lope le parece igualmente culpable en cuanto al teatro. Encuentra en Góngora la falta de orden que otros hasta entonces habían encontrado tan sólo en sus imitadores. "Góngora, dice, dotado de ingenio, y de phantasía muy viva, pero desreglada, y ambicioso de gloria, pretendió conseguirla con la novedad de el estilo, que en todas sus obras... es sumamente hinchado, hueco, y lleno de metáforas extravagantes, de equívocos, de antitheses, y de una locución a mi parecer de el todo nueva, y extraña para nuestro idioma» ${ }^{1}$. Más tarde, se queja de la supuesta oscuridad de Góngora, que se oponía directamente, según las teorías estéticas de Luzán, «a la belleza de la verdad" ${ }^{2}$. Se mofa de las "enmarañadas cláusulas» de las Soledades, e intenta demostrar cuán inadecuadas eran muchas metáforas en los sonetos de Góngora ${ }^{3}$.

Cuando Luzán publicó esta primera edición de su Poćtica en I737 era todavía bastante joven, habiendo cumplido treinta y cinco años apenas. Es posible que esto y su fervor nacional - su conciencia de las críticas francesas e italianas- le llevasen a expresarse con más rigor que justicia. Por cierto, al preparar más tarde la segunda edición de su libro, modificó bastante sus aseveraciones, sobre todo en lo que tocaba a Lope ${ }^{4}$. Y sus coetáneos no estaban del todo convencidos de la razón de lo que afirmaba, como se deduce de la reivindicación de Góngora y Lope que pronto apareció y que hubo de provocar luego nuevos ataques por parte de Luzán.

Se publicó esta crítica de Luzán y defensa de Góngora y de Lope en el Diario de los literatos, y la escribió Juan de Iriarte ${ }^{5}$. Nacido en el mismo año que Luzán, era uno de los jóvenes más inteligentes y mejor preparados de la época, y tenía una vasta erudición en materia de poesía, gracias, en parte, sin duda, a los excelentes maestros jesuitas que había tenido -_el famoso Charles Porée, y el no menos célebre La Sainte- du-

LuZÁn, La Poética. Zaragoza, 1737 , pág. I8.

2 Ob. cit., pág. 97.

3 Ob. cit., págs. 97 y 166 y sigs.

4 Compárense las referencias a Góngora y a Lope en la segunda edición, Madrid, I789, I, págs. 30-3I, con las de la primera edición, pág. I8.

5 Véase Diario de los literatos. Tomo IV, págs. I-62, recogido en las Obras sueltas de IRIARTE s. 1. I774, II, pág. 475 y sigs. 
rante su estancia en París en el colegio de Luis el Grande, donde habían estudiado Molière y Voltaire. Su crítica de Luzán iba al grano. Para rechazar sus asertos había que probar, entre otras cosas, la justicia de ciertas metáforas de Góngora, tachadas de extravagantes por Luzán. E. Iriarte lo consiguió mediante un minucioso análisis de las metáforas y su relación con su contexto: toda una explication de texte, en fin ${ }^{1}$. La técnica empleada por Iriarte y las razones que aduce demuestran su confianza en la estructura y saber poético de don Luis. Aunque su admiración no era tanta que tratase de defender las Soledades, al menos, ante el público, no vaciló en reconocer la fuerza imaginativa de las obras complejas de don Luis, y decía atinadamente que Luzán había comprendido mal el "poético espíritu» de Góngora, porque no congeniaba con la «idea sobradamente filosófica de las materias poéticas» que él tenía ${ }^{2}$.

Sin duda alguna, Iriarte era de los pocos estudiosos serios de Góngora por aquella época. Entre otras cosas parece haber entrevisto la importancia de los problemas textuales en su obra. Tenía una copia manuscrita de las Soledades con correcciones probablemente del puño de Góngora mismo $^{3}, y$, en septiembre de $\mathbf{I} 743$, acabó de cotejar otro tomo manuscrito de obras de Góngora con un tercer manuscrito que tenía a la vista . Según Salvá, ese segundo manuscrito «sería notable aun cuando fuese sólo por la pulcritud con que está escrito y por la importancia de las variantes que lleva apuntadas a las márgenes; pero es precioso por hallarse en él varias piezas que no [se encuentran] en ninguna de las ediciones» ${ }^{5}$. Lástima que se haya perdido este tomo.

No obstante la suave contestación de Luzán a Iriarte ${ }^{6}$, la línea de la crítica con respecto a Góngora seguía más o menos el criterio de Iriarte. Seguía vigente la admiración para con el propio Góngora entre la mayoría de los entendidos, aunque los críticos no cejaron los ataques contra los imitadores que continuaban existiendo. En realidad, si la Poética tuvo

1 Véase IRIARTE, Obras sueltas, II, págs. 492 y sigs.

2 Ob. cit., pág. 500.

3 Véase la historia de este manuscrito, que está ahora en la Biblioteca Bodleiana de Oxford, en José ANGer. Valente y Niger Glendinning, Una copia desconocida de las Soledades de Góngora, en el Bulletin of Hispanic Studies, XXXVI, I, I959, págs. I-I 4.

4 Véase Pedro Salvá y Maríín, Catálogo de la Biblioteca de Salvá, Valencia, I872, I, págs. 238-240.

5 Idem., loc. cit. A principios de este siglo Foulché-Dé,BOSC vio el manuscrito en una biblioteca particular en Francia. Véase su Note sur trois manuscrits des Oeuvres poétiques de Góngora, en la Revue hispanique, VII, I900, págs. 502-4.

- IÑIGO DE LANUZA, Discurso apologético. Pamplona, I740-4r. 
algún efecto, fue el de corregir a los imitadores más que cambiar la dirección de la crítica gongorina. Iriarte habia opinado que el libro era "muy conducente al desengaño público" ${ }^{1}, y$ es cierto que, entre los escritores de poéticas vidas de santos, hubo algún cambio de corazón por aquella época. En el prólogo a la Descripción harmónica de la vida y milagros de... San Antonio de Padua (Madrid 1748) incluso encontramos un fuerte ataque a los cultos por parte del autor de uno de estos poemas -Gómez Arias_- «Si eres de la Junta de los cultos, dice, en son de burla, estrañarás, que no haya en esta obra las voces de Pyra, Construye, Purpurizante, el Sol cadáver, trémula luz, explendores lánguidos del día, y toda la demás caterva de voces afectadas, irrisibles, y apartadas del buen lenguaje español» ${ }^{2}$. Reconoce que el estilo llano y sencillo es mejor para todas obras, y más que nada para las religiosas. Otro ataque a los cultos en la década cuarenta se encuentra en la aprobación escrita para las Poesias lyricas de Joseph Joaquín Benegasi y Luxán (Madrid I743) por fray Juan de la Concepción ${ }^{3}$. Este ataque tiene la particularidad de estar escrito en el mismo estilo que critica. Reza así:

No sé porque no ha de condenar la Eloquencia la Secta de los Anochecidos, como la Iglesia la de los Alumbrados. Estos hacen mérito la ociosidad culpable y aquellos publican adornos los capuces tristes. Quieren declarar a la Poesía, por hija bastarda de Febo, quando la coronan con el negro Pino de Pluto. El Corintho de España ha sido Córdova. Y como si fuera para todos el ir a Corintho, el anhelo de remedar al Superior Ingenio Cordovés, a muchos Españoles los ha hecho Griegos. Afectan aspirar a lo inmortal del Fenix, y se fixan el término en lo lúgubre de la Lechuza. ${ }^{4}$

El caso de fray Juan de la Concepción es interesante y no único. Creía evidentemente que él y algunos pocos más podían entender perfectamente a «nuestro insigne Góngora», $y$, por tanto, imitarle debidamente, sin incurrir en los extravíos de la turba de los cultos oscuros e ignorantes ${ }^{5}$. Despreciaba a los malos imitadores de Góngora, pero seguía admirando al original, e incluso en sus poemas le imitaba él mismo ${ }^{6}$. Lo mismo puede

1 Obras sueltas, ed. cit., II, pág. 500.

2 Ob. cit., Prólogo (páginas sin numerar).

3 JOSEPH JoAquín BeNeGasi y LUXÁn, Poesias lyricas y joco-serias. Madrid. I743, aprobación firmada en Madrid el ro de mayo de 1743 .

4 Idem., loc. cit., parcialmente citado por el MARQUÉS DE VArMAR en su Bosquejo histórico-critico, pág. IV.

s Véase el MARQUÉS DE VAlmar, Bosquejo, págs. XXXIII-IV.

- Véase el Diálogo métrico, Parma gozosa de "Juan de Madrid". Madrid, I745, poema de evidente inspiración culta, que se cree ser de fray Juan según el MARQỨs DE VAIMAR (B. A. E. 67, pág. VIII). Se encuentran muchas construcciones gon- 
decirse del amigo para cuyas obras fray Juan escribió la aprobación que acabamos de citar - Benegasi-. También él se mofaba de los «Ingenios cultos» en algunos de sus poemas ${ }^{1}$, y en un soneto alababa al autor de la Poética ("sentencioso es Luzán, y es admirable») ². Algún crítico se hacía lenguas de "la pureza de su estilo», afirmando que "no incurre en aquellas asperezas de palabras corpulentamente sonoras, o adulterinamente traídas». Sin embargo, Benegasi alababa no solamente los poemas sencillos de Góngora ${ }^{3}$, sino que también parece haber simpatizado con el otro Góngora, el cual "por su estilo remontado = De quien no le alcanzó, se vio abatido" ${ }^{4}$. Es de notar, además, que Benegasi se refería al padre Butrón como «ingenio de los mayores de este siglo», lo cual parece indicar que admiraba sinceramente el "elevado componer» de Góngora y a algunos de sus imitadores más inteligentes ${ }^{5}$.

La misma actitud se encuentra entre muchos de los que a principios de la década cincuenta formaban la Academia del Buen Gusto en casa de la marquesa de Sarria. Aunque Luzán era de su número, como también Agustín Montiano y Luyando, el propugnador del clasicismo en el teatro, muchos de los contertulios no estaban de acuerdo con ellos sobre el rechazo de Góngora y el estilo gongorino. En la «Fábula de Júpiter y

gorinas en el poema, sobre todo en las estrofas XVI, LXIX, IXXIV, LXXV, LXXXVII y XCI. No estamos completamente seguros de que la obra fuese escrita por fray Juan, sin embargo, ya que hay una aprobación de él. Extrañaria que aprobase su propia obra.

1 Véanse en la edición de sus Poesias lyricas, Madrid, 1752 , el soneto XXXVI en la pág. 57, y octava «Reparando el autor, que a imitación de nuestro célebre don Luis de Góngora, es raro el ingenio, que no tenga en sus obras algunas octavas, que empiecen con aquello de: Yo aquel, que en otro tiempo), en la pág. 7x.

2 Véase Poesias lyricas, ed. cit., pág. 6o (Soneto XL).

3 Véase la cita de "Hermana Marica", por ejemplo, en el prólogo de su Vida del portentoso negro San Benito de Palermo. Madrid, 1763.

4 Véase Poesias lyricas, ed. cit., pág. 39 (Soneto IV).

5 Véanse el Prólogo al lector de las Poesias lyricas, ed. cit., y el soneto XIII, página 43. En el Sueño en la exaltación del señor don Carlos $I I I$, atribuido al padre Isla cuando se publicó en Madrid en $7_{78}$, pero que se cree ser de Benegasi, se encuentra algún empleo jocoso del gongorismo: :Para decir mal dicho un disparate $=$ me sobran las especies que sugieren = quantos (gongoricemos) a montones $=$ esquinas entapizan papelones». Las Cartas atrasadas del Parnaso dirigidas a Benegasi como réplica al Sueño y publicadas con él en 1785 llevaron aún más lejos la burla del estilo gongorino. Véase, por ejemplo, la estrofa VII: "Alegórico-métrica Amaltea, $=$ Retórico-Symbólica derrama $=$ quanto thuribuliza a luz Febea, $=$ ephimera vernal vegetal llama = enfático-enigmática florea, = encomiástico-armónico epigrama $=$ que todo viene a ser un desatino = Zarati-Garcilasi-Gongorinos. Por aquella época se achacaba el abuso de los esdrújulos a Góngora. Algún crítico decia que su estilo debiera llamarse "gongórico». 
Europa», que su autor -el conde de Saldueña- leyó en la Academia, se encuentran varios recuerdos del Góngora de las Soledades y del Polifemo $^{1}$; el conde de Torrepalma, cuyo apodo académico muy sugestivo era "el Difícil» usaba con frecuencia giros gongorinos ${ }^{2}$; José de Villarroel también imitaba en sus poesías de vez en cuando a Góngora ${ }^{3} ; \mathrm{y}$, en las églogas de Porcel, según él mismo confesaba, hay bastantes "rasgos de luz» gongorinos "que ilustren las sombras» 4 .

De hecho, Porcel representa muy bien el punto de vista intelectual de los que seguían admirando a Góngora abiertamente en la Academia. Estaba muy lejos de ser un nuevo Nolasco o León y Mansilla. Su concepto de la poesía era mucho más clásico que el de ellos. La rígida forma de su serie de églogas $E l$ Adonis lo atestigua. Cada una de ellas ejemplifica el tema central, sirviéndose de parejas de amantes clásicos y terminando con una metamorfosis que prueba que uno hay amor en las selvas con ventura» ${ }^{5}$. Incluso se podría decir que el uso que hace Porcel del estilo gongorino en esa obra es más bien funcional que decorativo. Las metá-

1 Véanse, por ejemplo, la descripción del árbol en la estrofa XXXIV: "Verde estorvo del ayre, si grossero, $=$ honor robusto en pabellón copado $=\mathrm{da}$ el tronco, que sirvió al candor primero $=$ fruto barbaramente sazonado...n; o la de Júpiter transformado en un toro en LXXV: "La Luna, que en la frente le amanece, $=$ en su menguante muestra armados rayos". (D.D.A.D.S.F.D.C.C.D.S.M.D.C.Y.P., Fábula de Júpiter y Europa, s. 1., s. a., págs. I 4 y $27=$ De Don Alonso de Solís Folch de Cardona, conde de Saldueña, etc., según el MARQUÉS DE VALMAR, B. A. E. 67, pág. XII).

2 Imita abiertamente a Góngora (Soledad I, vv. 767 y sigs.) en su poema Invocación de Himeneo (B. A. E. 61, pág. 132) y hay construcciones gongorinas en el poema $A$ la Academia del Buen Gusto ("Cascado abeto, del sagrado mirto», págs. I28129) y en El juicio final (págs. 132 y sigs.).

3 Según el MARQués DE VAlMar (B. A. E. 6I, pág. XCII) imitaba alguna vez a Calderón en lo culto, y expresaba su admiración para los poemas sencillos de Góngora en el "Vexamen del Zángano" (i.e. Villarroel) sobre el "Marítimo" (Luis José Velázquez), citando "Al corral salió Lucía" y diciendo que la musa de Góngora ununca sopló... con más viento» que en ese poema. (Véase B. N. MSS. 18.476, número 2I). El otro Villarroel -Diego de Torres- que no sabemos si estaba emparentado con el de la Academia, fue mayor imitador de Góngora en sus poemas. Imita el "Mientras por competir con tu cabello", de Góngora, en su soneto a una dama ("Nace el sol derramando su hermosura", soneto medio correlativo y algo más cerca de Góngora que la imitación del mismo soneto por Gerardo Lobo), y recuerda el último verso del mismo soneto de Góngora en otro que empieza «La tierra, el polvo, el humo, en fin, la nada». También hay evidentes huellas de Góngora en su Oración "Cómo azotas en vano!» (B. A. E. 6I, págs. 62-3), y alababa a "Góngora, Lope y otros, que la idea $=$ De las Musas siguieron altamente» en otro soneto.

- Véase B. A. E. 6r, pág. ${ }^{4}$ o.

- Véase B. A. F. 6r, pág. I4I. 
foras atrevidas son menos frecuentes que los cultismos ("nocturno dia»; "émula vana», "luz febea", "canoro instrumento», "dios mentido", etc.), y éstos contribuyen perfectamente a la atmósfera clásica de las églogas. Además, aunque se jactaba de imitar en su Adonis «en especial al incomparable cordobés... (delicias de los entendimientos no vulgares)" ${ }^{\mathbf{1}}$, Góngora no era su único modelo. El fondo y la forma de la obra debían tanto o más a Garcilaso que a Góngora. El tema central de la desgracia que acompaña al amor sensual está tomado al parecer de las tres églogas de Garcilaso. Y si bien es cierto que encontramos en El Adonis muchas de las construcciones típicas de Góngora, y algunas de sus metáforas- $« \mathrm{Fa}-$ tigar las selvas» (para la caza), "Verde dosel frondoso» (para las hiedras con los árboles), «líquida sierpe sonora» (el arroyo), y «limpios trastes del líquido instrumento" (las blancas guijas del arroyo) ${ }^{2}$, por ejemplono lo es menos que encontramos, en el mismo poema, algunos «rasgos de luz», y aun versos enteros, de Garcilaso ${ }^{3}$. Sin duda alguna, la poesía renacentista era tanto o aún más de admirar para él que la barroca. A diferencia de la mayoría de los imitadores de Góngora, es de creer que Porcel admiraba el fondo clásico (y renacentista) de la inspiración de don I uis más que sus colores llamativos.

Por moderado que fuese el gusto gongorino de académicos tales como Porcel, no agradaba nada a los verdaderos reformadores de la tertulia, los cuales querían acabar por completo con la influencia de Góngora, que tan peligrosa les parecía. Entre éstos se destacaban, además de Luzán y probablemente Montiano, Juan de Iriarte y Luis José Velázquez, el marqués de Valdeflores. En vista de las continuas imitaciones del Góngora difícil, Iriarte parece haber modificado su opinión con respecto a Góngora en la década cuarenta, siendo por entonces menos tolerante de lo que había sido en $1737^{4}$. Velázquez, casi desde el principio, parece haber

1 Idem, loc. cit.

2 Comparación muy grata a Góngora. Véanse, por ejemplo, Soledades I, vv. 345-347, II, vv. 349-350, y la Canción "Sobre trastes de guijas» (MrL, É, Madrid, 1943, núm. 390). Se encuentran los pasajes de PorCEI en B. A. E. 6r, págs. I4r, $146,149^{\circ}, 149^{b}$ y $149^{b}$.

8 Véase B. A. E. 61, pág. $156^{3}$, donde se encuentra el verso umás duro que mármol a mis quejas». En un soneto PORCEL cita la tercera égloga de Garcilaso y el soneto "Oh dulces prendas, por mi mal halladas» (B. A. E. 6r, pág. I73).

4 IRIARTE se mofa de Góngora en dos epigramas. (Obras sueltas, s. 1., I774, I, página I28 -Epigrama CDXLVII, y pág. 248- Epigrama XII.) También creemos que son suyos ciertos comentarios satíricos de tres lugares de la Primera Soledad que se encuentran manuscritos en el Museo Británico (Add. 20, 793, f. 267-268), aunque pudieran ser de su sobrino Bernardo de Iriarte. Es interesante el que en estos comentarios tome el pasaje del carbunclo (I, 62-83) por una descripción 
seguido a I,uzán, y su posición en los debates sobre Góngora queda bastante clara, gracias a las cartas que escribió a Montiano, las Actas de la Academia del Buen Gusto, y sus obras impresas.

Ya en $\mathrm{I} 753$, en el discurso que incluyó en la segunda edición de las Poesias que publicó don Francisco de Quevedo... con el nombre del Bachiller Francisco de la Torre (Madrid I753, pág. XVII), Velázquez hablaba de Góngora como runo de los malos poetas de su siglo, que havían empezado a corromper la Lengua, y la Poesía Castellana con el uso de voces bárbaras, y obscuras, con frecuentes latinismos, con el estilo hinchado, y lleno de vano estrépito, con imitaciones frívolas, afectadas, e impertinentes, y con los demás vicios propios del Lenguaje, y estilo, que en aquel tiempo se llamaba Culto». Lamentaba que algunos de los que formaban parte de la Academia fuesen de los que «sienten por la parte opuesta al buen gusto" $\mathrm{y}$, por tanto, disintiesen de su dictamen ${ }^{1}$. Al preparar sus Origenes de la poesía castallana (Málaga r754), por entonces, decía a Montiano que no quisiera mencionar en su libro al conde de Torrepalma. ni a Porcel («de quien sólo son buenos algunos pedazos»), aunque se sentía obligado a hacerlo por razones de amistad ${ }^{2}$. Ya había reñido con ellos sobre Góngora, y reconocía que su nuevo libro iba a levantar más "polvo», por lo que decía en él de Góngora, Calderón y Lope ${ }^{3}$.

Con respecto a Góngora, repite Velázquez, más o menos, lo ya dicho por Luzán en su Poética. Según sus cartas, quería que éste, con Montiano e Iriarte, añadiesen o quitasen lo que mejor les pareciera a los Orígenes antes de su publicación, y les envió el manuscrito a este efecto 4 . Vuelve a citar la obra de Pedro Nolasco como caso notorio del mal gusto corriente

de kuna encina que los labradores avian quemado $\mathrm{p}^{\mathrm{a}}$ hoguera», vista desde lejos, relacionándola con el "Vulcano" de v. 93, sin duda, y no con un verdadero farol. Es curioso, en cambio, que no diga nada del carbunclo mismo, a pesar de que la leyenda del animal que llevaba aquella piedra en la frente seguia existiendo en el siglo xviIr. Feijoo se refiere a él en su Teatro crítico (II, Discurso segundo, § VI). La explicación que el padre Feijoo da del carbunclo justifica plenamente la interpretación de Iriarte: "Carbunculus, dice, ...no significa otra cosa que el Rubí; (a quien se dio tal nombre, porque representa un carbón encendido)".

1 Véase la carta a Montiano y Luyando fechada en Mérida, el 23 de marzo de 1753 , B. N. MSS. I 7546. Las siguientes cartas vienen del mismo tomo manuscrito, que está sin foliar.

2 Véase la carta a Montiano fechada en Mérida el zo de marzo de 1753.

* Véase la carta a Montiano fechada en Mérida el 1 $_{3}$ de abril de I753. También en una carta escrita de Granada (23 de octubre de 1753 ) dice haber reñido con Porcel umás de una vez sobre Góngora; $y$ ha pateado luego $q^{\mathrm{e}}$ le vio colocado entre los malos poetas en el discurso al Bachiller de la Torre. Discurra V. lo q. havrá en saliendo a luz los Origenes...".

4 Véase la carta a Montiano fechada en Mérida el 4 de mayo de 1753. 
entre los imitadores de Góngora, y aprueba la crítica hecha de él y de ellos en el Diario de los literatos ${ }^{1}$. Por fin, como Luzán, echa la culpa de toda la decadencia de la literatura a los cultos, y en especial a Góngora, Paravicino y Gracián. Para mayor claridad, divide la historia de la literatura española en cuatro edades, resultando ser la de Oro (sólo digna de imitación) el Renacimiento español. Casi todo lo que venía después de r6oo (excepción hecha de los Argensola, Quevedo y algunos más) era decadencia. Ya se ve que los «buenos pedazos» en las obras de Porcel para Velázquez serían aquellos en que imitaba a Garcilaso más que a Góngora.

Velázquez y sus amigos esperaban que los Orígenes y otras obras que proyectaban acabasen de desterrar el gusto barroco (o sea, la visión rococó del barroco) de España, y estableciesen allí los mismos moldes clásicos que privaban, por entonces, en Francia e Italia ${ }^{2}$. Les alentaría mucho, sin duda, el que los jesuitas franceses redactores de las célebres Memorias de Trévoux aprobasen sus labores ${ }^{3}$. No les alentaría menos e] que los jesuitas en España también les ayudasen prácticamente a diseminar las teorías neoclásicas ${ }^{4}$. No dejan de llamar la atención las estrechas relaciones entre los espíritus reformistas y los jesuitas en España. Luzán e Iriarte fueron alumnos de ellos en Italia y en Francia; el marqués de Valdeflores, alumno de la Compañía en Granada, fue preso y desterrado más tarde, sospechoso de haberles ayudado ${ }^{5}$. Sin duda alguna, la

1 Ob. cit., pág. 72.

2 En su carta a Montiano, fechada en Málaga el io de junio de I755, habla de $1 a$ proyectada «Colección de las mejores poesías castellanas desde el origen de la buena poesía hasta el tiempo presente». Iban a colaborar con Velázquez en el proyecto Montiano, Llaguno y Juan Trigueros. Velázquez habla de otros proyectos literarios y patrióticos en una larga carta a Montiano escrita en Málaga el 28 de abril de 1755 .

3 Véase, sobre todo, la larga reseña elogiosa de la Poética de Luzán, en las Mémoires pour l'histoire des sciences et des beaux arts, mayo 1748, pág. 995; junio, pág. I248, y julio, pág. I438. El padre Burriel estaba seguro de la buena acogida de los Origenes en Francia, según carta de Velázquez a Montiano de Málaga, el 12 de noviembre de 1754 .

4 Eil que los jesuitas enseñaban las teorias neoclásicas en España se deduce de sus publicaciones. Véase, por ejemplo, la Colección de varios tratados curiosos propios y muy útiles para la instrucción de la noble juventud española, que publica el Real Seminario de Nobles de Madrid. Madrid, 1757, y los varios Exercicios literarios publicados por el mismo Seminario.

5 Véanse la vida de Luzán en la segunda edición de su Poética (Madrid, 1789, dos tomos), y la de Iriarte en sus Obras sueltas (ed. cit.). Se refiere a la prisión del marqués de Valdeflores en el Memorial ajustado de la causa criminal que a instancias del ilustrísimo señor don Pedro Rodriguez Campomanes... ha sustanciado el señor don Agustin de Leyza... (Barcelona, I768). 
influencia de los jesuitas en la educación de la nobleza y de los intelectuales españoles de la época contribuyó enormemente - tanto o más probablemente que los libros de Luzán y Velázquez - al auge de neoclasicismo y al destierro de Góngora y del estilo oscuro en la literatura española en las décadas cincuenta y sesenta, y en la generación que se formó en sus colegios por entonces.

Hacia fines de la década cincuenta dos preceptistas y un novelista volvieron a afirmar los principios clásicos en obras de gran difusión, y completaron las labores de Luzán y Velázquez: nos referimos al padre Burriel, jesuita, cuyo Compendio del arte poético (Madrid 1757) mereció las alabanzas de las Memorias de Trévoux 1; a Mayáns y Siscar, quien, en su Rhetórica (Valencia I757), condenó rotundamente las metáforas extravagantes y demás "vicios» de Góngora 2; y al padre Isla, otro jesuita, cuya novela Fray Gerundio de Campazas (primera parte, Madrid I758) trataba de desterrar el estilo culto entre los predicadores ${ }^{3}$. Tales obras, juntas con la educación jesuítica que favorecía las mismas normas, acabaron con el culto al Góngora difícil, al menos entre los intelectuales que querían que la literatura española se pusiese de nuevo al nivel de los demás países de Europa. Desde entonces en adelante sólo los poetas de cultura muy mediana podían alabar abiertamente al autor de las Soledades y del Polifemo. El padre Sarmiento, que antes incluía a Góngora y sus comentaristas entre los libros que merecían ser comprados por quienes deseasen poseer "de tres a quatro mil tomos», decía en una carta del II de febrero de $\mathbf{1 7 6 3}$, escrita a su amigo Francisco de Mena: «Vayan por la ventana y al infierno las Soledades de Góngora, en Lengua no castellana, sino de la California» ${ }^{4}$. E incluso algún que otro poetastro como Francisco Nieto Molina aprendió, al fin y al cabo, que más valía mofarse del Góngora oscuro que elogiarle 5 .

Tales críticas llevaron acaso a nuevos extremos de vituperio y adula-

1 Véanse las Mémoires, noviembre 1758, pág. 2865. El que el padre Burriel estaba de acuerdo con las ideas de Velázquez se deduce de la carta de éste a Montiano escrita desde Málaga, el i 2 de noviembre de 1754 .

2 Véase ob. cit., II, págs. 6, 50, 330, 347-8, 364, 360 y 516. Mayáns sólo elogia los romances de Góngora y algún soneto en esta obra.

3 Véase sobre las teorias estilisticas del padre Isla la introducción a la reciente edición de Fray Gerundio. Madrid, Clásicos castellanos, 1960, págs. I.VIII y sigs. Hay una referencia al notorio poema de Pedro Nolasco en la pág. roz.

4 Véase Semanario erudito, V, Madrid 1787, pág. I73; y, para la carta, MSS, de la Real A.cademia de la Historia, Est. 20 gr. $7^{\mathrm{a}}$, y núm. 90.

5 NiETo DE Molina se refiere a Góngora como uun assombro de los líricos» en El Fabulero (Madrid, 1764), pero se mofa de él y '!t - u estıl., (u su Inventiva vara, definición de la Poesia contra los poetas equivoquistas, Madrid, 1767. 
ción obstinada, y los escritores tuvieron que volver por Góngora en lo subsiguiente. Por lo menos López de Sedano, a principios de la década setenta, lanentaba tales extremos, diciendo que había que llegar a un justo medio con respecto a don Luis ${ }^{1}$. Pero ya no se trataba de reivindicar al Góngora difícil de los poemas largos, sino al de los poemas cortos que hasta entonces habían gustado, aun a los literatos de más depurados gustos clásicos. La colección del Parnaso español, por tanto, incluyó unos pocos romances y letrillas de Góngora para probar su buen gusto en los poemas cortos. (Entre ellos se encuentra también una pequeña muestra de «los vicios de la hinchazón y afectada cultura» en los que Góngora podia incurrir, para que se supiese evitarlos ${ }^{2}$.) Sin embargo, tan duras habian sido las críticas anteriores, que ni estas pruebas del buen gusto gongorino, ni las conocidas initaciones de romances y letrillas de Góngora por Nicolás Fernández de Moratín, García de la Huerta, Cadalso, Meléndez Valdés e Iglesias de la Casa, bastaron para restablecer a Góngora debidamente. $Y$, a mediados de la década ochenta, el profesor de poesía en los Reales Estudios de San Isidro, López de Ayala, opinaba que era muy necesario que «se explicase el sobresaliente mérito de [las] poesías menores [de Góngora], advirtiendo la diferencia de estilo que hay entre ellas y las mayores; pues vituperado en éstas por usar de frases muy figuradas y oscuras, le desacreditan injustamente en las demás poesías, que son de las más sencillas, numerosas y delicadas $q^{e}$ ay en la Lengua Castellana” ${ }^{3}$.

Gracias a esta opinión de Ayala, el tomo IX de la Colección de poetas españoles hecha por "Ramón Fernández», llevó un largo prefacio crítico cuando salió en I789. Se volvió a elogiar en él el ingenio sublime, erudición y superior talento de Góngora como poeta, quejándose tan sólo de la falta de proporción y arreglo de los poemas largos. En cuanto a éstos el prologuista no modificó en nada la opinión de Luzán y Velázquez, encontrando en ellos la misma disonancia entre la forma y el contenido que aquellos críticos y otros habían reparado. Para él, el estilo de las Soledades era tan caprichoso como el de los imitadores, y comparaba la obra a «aquellas nubes que, miradas desde lejos, parecen una dilatada cordillera de montañas; pero, tocadas de cerca, se ve que no son más que vapores que huyen al tacto" ${ }^{4}$. Ultimamente decía que se podía afirmar

- Véase Parnaso español, tomo VII, Madrid, I773, pág. XVIII.

2 Idem. Indice, pág. XVI. Se trata de la Fábula de Piramo y Tisbe.

3 Véase su censura para la edición de poesias de Góngora hecha por "Ramón Fernández», A. F. N. Consejo Leg. ${ }^{\circledR}$ 5550, núm. 45.

- Ob. cit. pág. 9. 
su falta de arte con completa confianza, ya que no habían resistido a "las pruebas del tiempo». Plena indicación de ello era, según él, "el ningún caso que hacen en el día los sensatos de las Soledades» ${ }^{\mathbf{1}}$.

¿Es cierto este aserto? Desde luego, no podemos estar completamente seguros de ello. Es verdad que Cadalso creía que si "Góngora y sus desatinados secuaces» habían imitado cierto estilo, "era menester huir de tal camino por no dar en iguales precipicios» ${ }^{2}$; que para Forner, la gente que seguía a Góngora era "la caterva necia» 3; y que Tomás de Iriarte, sobrino de don Juan, confesaba en un célebre soneto que leía las Soledades sólo porque necesitaba la conciencia de lo malo para poder disfrutar mejor de lo bueno ${ }^{4}$. En cambio, el marqués de Valdeflores dejó unos comentarios manuscritos a las obras de Góngora ${ }^{5}, \mathrm{y}$, muchas veces, el giro de las frases de poetas tales como Huerta, Cadalso y Leandro Fernández de Moratín nos parece recuerdo de lecturas gongorinas. Pero hay que andar con tiento en esto de las influencias. Los comentarios podían ser satíricos - como algunos de Juan de Iriarte-y es muy difícil, en muchos casos, distinguir entre imitaciones de Góngora y las de Herrera, que era el verdadero modelo para la poesía pindárica y heroica de los neoclásicos. Al menos no hemos encontrado ningún recuerdo evidente del Góngora difícil en los poetas importantes de las décadas setenta y ochenta, y creemos que todo lo que no fuese romance, letrilla o poema corto en Góngora estaba, en efecto, olvidado por los poetas y críticos «sensatos» de aquella época. Si se seguía apreciando al "Marcial andaluz», se despreciaba generalmente al "Homero español» ${ }^{6}$.

Hubo, no obstante, algún momento en que parecía posible que incluso «los sensatos» en materia poética iban a apreciar de nuevo las obras largas

$1 \quad$ Idem, pág. 8.

2 Véase la carta de Cadalso a un amigo desconocido sobre el estilo pindárico en mi artículo Ortelio en la poesía y en la vida de Callalso en la Revista de Literatura, 1958, XIV, 27, págs. 22-3.

3 Véase B. A. E. 63, pág. 309a

4 Véase el famoso soneto "Respuesta del autor a un curioso que le preguntó qué gusto hallaba en leer las Soledades de Góngora, en la Colección de obras en verso y prosa de don Tomás de Iriarte, II, Madrid, I787. Soneto XIII.

5 Entre las obras de Velázquez mencionadas por el MARQUES DE VAIMAR (B. A. F. 67, pág. 554) se encuentran unas Lecciones gongorinas manuscritas. No hemos podido encontrar esta obra, y no sabemos si se trata de un comentario serio, o, como el de Iriarte, satírico.

- Véase, por ejemplo, la "Silva en loor de los ilustres poetas sevillanos» (1796) de Fú́IIX JosÉ REINoso en B. A. E. 67, pág. 229, y lo que dice ForNER de *los epigramáticos [guiados] de Góngora" en sus Exequias de la Lengua castellana, en B. A. F. 63, pág. $45^{\mathrm{b}}$. 
de don Luis. Con la creciente oposición al gusto francés por razones nacionales en la década ochenta, algunos se volvieron hacia los estilos que, a su parecer, reflejaban el fogoso carácter nacional mejor que el clasicismo. (Por entonces la ridícula idea de un carácter nacional estaba muy de moda.) Forner, por ejemplo, después de criticar a los imitadores de Góngora en su Sátira contra los vicios introducidos en la poesía castellana (I782) ${ }^{1}$, con escasas y ambiguas reservas con respecto a Góngora mismo, vuelve por algunos de ellos en sus Exequias de la Lengua castellana. Por boca de "Arcadio" dice que "conociendo yo muy bien cuánto se extraviaron del buen gusto muchos poetas de los tiempos de Felipe IV y Carlos II, prefiero sus sofismas, metáforas insolentes y vuelos inconsiderados, a la sequedad helada y semi-bárbara del mayor número de los que poetizan hoy en España» ${ }^{2}$. Pero, a pesar de este ataque al neoclasicismo más débil, no llega a defender a Góngora. Al tratar de él en la misma obra, no altera en nada los criterios comunes entre los neoclásicos. Le aprecia como jefe de los poetas epigramáticos, pero habla despectivamente de "la tenebrosidad gongorina" y de las "destempladas novedades de Góngora» ${ }^{3}$.

Todavía más cerca de justificar el estilo culto y a Góngora llegó por la misma época el prologuista de las Rimas de Fernando de Herrera (Madrid, I786), probablemente Pedro Estala ${ }^{4}$. Igual que Forner, apreciaba «el lenguage poético, y sublimidad de estilo" de la poesía española, y, en especial, de Herrera ${ }^{5}$. Y temía la influencia del estilo prosaico, típico, según él, de la poesía francesa que se imitaba por entonces en España. Hasta admiraba en Herrera «las muchas voces nuevas poéticas con que enriqueció nuestro lenguaje" ${ }^{6}$ - muchas de ellas iguales a los cultismos usados por Góngora-. Pero cuida de distinguir, luego, entre la disciplina y moderación de Herrera y el desarreglo y extravagancia de otros cultos. $\mathrm{Y}$ aunque no menciona específicamente a Góngora, encontramos entre los ejemplos de las metáforas excesivas que cita alguna de las caras a don Luis? ${ }^{7}$. Por fin, en otro tomo de la misma colección Estala alaba

1 Véase B. A. E. 63, pág. $309^{\mathrm{a}}$.

Idem, pág. $397^{\mathrm{a}}$.

Idem, pág. $4^{16^{\mathrm{a}}} \mathrm{y}^{\mathrm{b}}$.

- Véase MENÉNDEZ y PeIAYO Historia de las ideas estéticas en España.

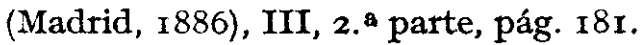

¿ Ob. cit. (Tomo IV de la Colección de poetas españoles de "Ramón Fernándezi), pág. 4 .

- Ob. cit., pág. 18.

7 Ob. cit., pág. 3 I. Cita la metáfora "citara de cristal con traste de oro" para describir el arroyo, que es muy parecida a las usadas por Góngora en las Soledades, I, vv. 345-7; II, vv. 349-5o; y en la Canción, MILLí, núm. 39o, vv. I-2. 
abiertamente una de las sátiras de Jáuregui, en la que parodiaba el estilo de la Toma de Larache $^{1}$, y ya sabemos lo que él o uno de sus amigos. decía más tarde en el prólogo que trataba de Góngora.

En la déclada ochenta se volvió a publicar la Poética de Luzán, y en la noventa, los Origenes del marqués de Valdeflores ${ }^{2}$. Aunque se seguían imitando los romances y letrillas de Góngora a fines del siglo y principios del xIx, ninguno de los poetas mayores de la época parece haberse inspirado en las Soledades o en el Polifemo. Cienfuegos, cuyos vuelos poéticos chocaban a algunos de sus coetáneos, fue el único que se acercó alguna vez al estilo gongorino. $Y$, por cierto, algún crítico le creía sospechoso de "gongorizar" voluntariamente ${ }^{3}$. Pero, en realidad, fue a Herrera y no a Góngora, como tantos otros, a quien Cienfuegos admiraba e imitaba 4. $\mathrm{Y}$ los demás poetas de la época siguieron a Meléndez y a Leandro Fernández de Moratín en respetar los criterios clásicos de la generación anterior. Entre los críticos - Vargas Ponce, Quintana, Martínez de la Rosa y Alberto Lista ${ }^{5}$ - , tampoco hubo cambios de ideas. Quintana se las daba de innovador en la crítica, y podía mofarse de las teorías de Luzán y de Iriarte con respecto a Góngora ${ }^{6}$. Pero no decía nada en absoluto que ellos y otros no hubiesen dicho antes. Y si tenía razón al decir que el estilo de las Soledades se encontraba en "casi todos [los] sonetos y canciones [de Góngora], salpicando también... bastantes pasages de sus romances y letrillas», otros críticos antes de él habian sabido muy bien que no se podian exceptuar todos los poemas cortos del llamado «mal gusto» gongorino?.

A pesar de ello, no se puede decir nunca con absoluta seguridad que el

1 Véase "RAMón FernándfZ», Rimas de don Juan de Jánregui (2. a ed. consultada. Madrid, 1819), pág. 9. La primera edición es de 1786.

2 La Poética de Luzán. Madrid, 2 tomos, 1789; Los origenes, de IrUS José: VEI,ÁzQUEZ, Málaga, I797.

3 Véase el Fixamen del juicio crítico de los principales poetas españoles de la hiltima era, por JUAN NICASIO GAIIIEGO, en B. A. E. 67 , pág. $429^{b}$.

4 Gracias a los papeles de la censura sabemos que Cienfuegos pidió permiso "para reimprimir las poesias de Fernando de Herrera" en I784 (A. H. N. Consejo Ieg. ${ }^{\circ} 555^{\circ}$, núm. 44). No llegó a publicar el tomo.

5 Véanse Josî́ DE VARGAS Y PONCE, Declamación contra los abusos introducidos en el castellano (Madrid, 1793), pág. I 38; M. J. Quintana, Tesoro del Parnaso español (Perpiñán, I817), I, págs. XCIII-XCVIII; MARTíNEZ DE LA ROSA, Obras Literarias (Londres, 1838 ), I, págs. 84, 92, etc.; y Ar,BERTO LISTA, Ensayos literarios $y$ criticos (Sevilla, I844), I, págs. I9-20.

- Quintana, Tesoro del Parnaso español (ed. cit.), I, pág. XCIII.

7 Véanse, por ejemplo, los comentos que se hacen a la Fábula de Leandro $y$ Hero en el Parnaso español, VII, Madrid, 1773, indice, pág. XVI. 
Polifemo y las Soledades fuesen olvidados por todos. Sólo sabemos que los que se preciaban de "sensatos» solían despreciarlos. Ya que Cadalso y, más tarde, Leandro Fernández de Moratín y Lista siguieron criticando el estilo culto entre sus contemporáneos, es casi cierto que al Góngora difícil y a sus imitadores no les faltaban admiradores en plena época neoclasicista ${ }^{2}$, aunque no se les admirara oficialmente por entonces, ni volvieron - por Góngora tampoco los que rescataron a Calderón a principios del siglo XIX como antítesis del estilo clásico francés. Era difícil que se volviese por Góngora entonces, porque las razones religiosas y nacionalistas (más que estéticas) que ocasionaron la reivindicación de Calderón en España no podían aplicarse tan fácilmente a la poesía de don Luis. Además, los críticos extranjeros (Schlegel y Böhl de Faber entre otros) que contribuyeron tanto a la vuelta por Calderón, no estimaron a Góngora. Para el poeta inglés Southey, Góngora era la rana de la fábula: grande de talla, pero grande gracias a la hidropesía. Después de desentrañar el intrincado sentido de sus obras, Southey decía, "se siente uno como un hombre que ha cansado sus mandibulas en cascar una nuez vacía” ${ }^{2}$. No creemos que muchos literatos en Francia, Alemania o Italia hayan pensado de manera muy distinta ${ }^{3}$. Sólo el bibliófilo Heber en Inglaterra, y algunos pocos

1 Véanse los títulos barrocos de libros publicados en Madrid entre 1757 y I774 en la carta LXXVII de las Cartas marruecas; la Sátira contra los malos escritores de este tiempo, de IFAndro Frarníndez de Moratín, y el largo poema de LISTA, El imperio de la estupidez ( 7 798), en el cual se refiere a «una sucesión no interrumpida /de monstruos de las nieblas/ = Desde el divino Góngora hasta ahora", (Véase B. A. E. 67 , pág. $380^{\circ}$ ). De los títulos de muchos de los poemas heroicos publicados en la segunda mitad del siglo parece cierto que el gusto barroco no estaba del todo muerto por entonces. (Véase la lista del MARQUÉs DE VArMar en B. A. E. $6_{7}$, págs. VII-XIV. Sumando aquellos poemas y exceptuando los de autores notoriamente neoclásicos, llegamos a la cifra de 89 para los escritos entre I 700 y $175^{\circ}$, y 86 para los escritos entre 1750 y I 800 , poco más o menos.)

2 Véase Southey's Common-place book, ed. JOHN WOOD WARTER. 2. ${ }^{a}$ serie, L.ondon, I 849 , pág. 209.

3 En Inglaterra los historiadores de la literatura española solían seguir las normas neoclásicas en cuanto a Góngora (véanse, por ejemplo, DILLON, Letters from an English Traveller in Spain in 1778 on the origin and progress of Poetry in that kingdom, London, $\mathbf{1 7 8 \mathrm { r }}$; y ROBERT SOUTHEY, Letters written during a short residence in Spain and Portugal. Bristol, 1797). En Alemania hubo traducciones del libro de Dillon y de los Origenes de Velázquez, y no se acogieron bien las versiones alemanas de romances de Góngora hechas por J. G. Jacobi; (véase HerberT O. LyTE, Spanish Literature and Spain in some of the leading German Magazines of the secon half of the eighteenth century. University of Wisconsin Studies in Language and Literature, núm. 32, 1932, passim); el crítico Bouterwerk, a principios del siglo xIx, no cambió para nada las opiniones neoclásicas con respecto a Góngora. En Francia, SisMondr siguió las mismas normas en su libro De la 
más, parecen haber leído al Góngora difícil con cierto gusto ${ }^{1}$. Y aun cuando ellos apreciasen verdaderamente al autor de las Soledades, casi nadie se habrá enterado de sus opiniones.

Aun cuando no se pregonase la afición, siempre la hubo tanto para el Góngora "difícil» como para el otro, en los siglos xvirr y xIX, al parecer. Como en el siglo xvir, la poesía de Góngora seguía provocando, por entonces, las opiniones más diversas y contrarias, la mayoría de ellas, al menos, respetuosas. La misma admiración para los romances de Góngora que se encuentra en Cascales vuelve a encontrarse en Mayáns y en Martínez de la Rosa; la misma reserva para los poemas largos. Y si el abad de Rute y otros defendieron, coleccionaron y comentaron a Góngora a principios del siglo xVIr, Iriarte y otros no lo hacian menos cien años más tarde ${ }^{2}$. Incluso las Soledades y el Polifemo volvieron a tener sus partidarios a mediados del $\mathrm{xrx}$, por muy olvidados que estuviesen durante la segunda mitad del siglo XVIII ${ }^{3}$.

ittérature du midi de l'Europe (3. ${ }^{\text {a }}$ ed. consultada, París, I829, IV, págs. 54-63), y hubo también traducciones de Bouterwek y de Dillon (Essai sur la littérature espagnole, publicado en Paris sin nombre de autor, 1810). Huelga decir que los exilados, que tanto influyeron sobre los gustos españoles en Inglaterra y en Francia, fueron por la mayor parte neoclásicos. En Italia, a fines del siglo XvirI, habian influido mucho los jesuitas desterrados. Ia famosa obra del padre ANDRÉs, Dell' origine, de' progressi e dello stato attuale d'ogni letterarura (Parma, I782), no habia siquiera mencionado a Góngora.

1 Para detalles de las aficiones gongorinas de Heber, véase José ANGEL, VALENTE y NIGEI, Glendinning, articulo citado. Sabemos que Heber entendía lo que leia, y no era mero poseedor de libros, gracias al testimonio de GALLARDo en El Criticón, núm. 4 (Madrir, 1836), pág. 4.

2 Aparte de la colección de Iriarte ya mencionada, sabemos que el ministro aragonés Roda coleccionaba obras manuscritas de Góngora y sus comentarios. Entre sus manuscritos, que legó al seminario de San Carlos de Zaragoza, se encuentran un tomo de "Sonetos heroicos y muchos otros versos de don Luis de Góngora y Argote" (MS. del siglo XVIr, núm. 9496 del seminario), y una "Introducción a la Soledad primera de don Luis de Góngora ylustrada y defendida" (MS. del siglo XVIr, número 14458 del seminario). GaI,LARDO, en sus investigaciones bibliográficas, vio varios otros manuscritos gongorinos en colecciones particulares (véase Ensayo de una biblioteca española de libros varos y curiosos, Madrid, I889, IV, págs. I214, I 229 y I234, números 4431 y 4436).

3 Luis María Ramírez, en su tomo de Poesias escogidas de don Luis de Góngora (Córdoba, 184r), cita variantes de diferentes manuscritos, aunque no le agrada el Góngora «dificil\%. MANUEL, GONZArEZ LIANA, en cambio (Poesias selectas de don Luis de Góngora, Madrid, 1868), incluye el Polifemo en su colección, y respeta la "gran sublimidad en las ideas, y el más brillante colorido" de los poemas difíciles. Igual vuelta por el Góngora de los poemas largos se encuentra en el prólogo y colección de Góngora entre los "Poetas líricos de los siglos XVI y xvII, hechas por ADOLFo DE CASTRo para la B. A. E., tomo 32, en 1854 . 
¿Hay alguna lección para nosotros en la crítica que se hacía de Góngora en el siglo xvirr? Creo que sí. La importancia que los críticos de aquella época daban a la relación entre el estilo y el contenido de las obras sigue siendo muy justa. Algunos de ellos (aunque no los imitadores de Góngora en la primera mitad del siglo) parecen haber comprendido perfectamente la importancia de esa relación en la obra de Góngora y reconocido su buena estructuración. En cambio, la crítica moderna hasta hace poco lo ha ignorado o desestimado, influida quizá por la estética del arte por el arte. ¡Cuántas veces en este siglo se ha apreciado el estilo, el colorido y todo lo demás de la "corteza" de las obras de Góngora por sí mismos, precisamente como Gerardo Lobo, Pedro Nolasco y tantos otros imitadores del siglo XVIII, que ahora despreciamos! Es cierto que muchos críticos dieciochescos tenían un concepto demasiado estrecho de la función del estilo en el arte; también es cierto que algunos de ellos atacaron a Góngora sin razón por confundir su técnica con la de los imitadores. Sin embargo, en el fondo sus criterios no eran malos, aun cuando abusasen de ellos de vez en cuando. Por esto, el estudio de su crítica será siempre muy sano, y el examen de sus imitaciones instructivo. Góngora es único y quizá estas críticas tan rígidas e imitaciones bastante malas nos ayuden a precisar el cómo y el porqué.

NigeL, Glendinning.

Universidad de Southampton, 